\title{
Orientocreadium batrachoides Tubangui, 1931 (Orientocreadiidae): The only Trematode Parasite of Clarias gariepinus (Burchell, 1822) (Clariidae) from the Asi River (Southern Turkey)
}

\author{
Asi Nehri'nden Yakalanan Clarias gariepinus (Burchell, 1822) (Clariidae)'un Tek Trematod \\ Paraziti: Orientocreadium batrachoides Tubangui, 1931 (Orientocreadiidae)
}

\author{
Yahya Tepe ${ }^{1}$, Mehmet Cemal Oğuz¹, Mark Belk², Remzi Özgen \\ 'Department of Biology, Faculty of Medicine, Atatürk University, Erzurum, Turkey \\ ${ }^{2}$ Department of Biology, Brigham Young University, Salt Lake, USA
}

\begin{abstract}
Objective: Some information is available about the parasite fauna and incidence for Clarias gariepinus in Turkey, but digenean parasites have received little attention. The purpose of the study is to contribute to the parasite fauna of Turkey.

Methods: From 2007 to 2008, a total 63 Clarias gariepinus that were caught in the Asi River were purchased from the fish market in Hatay and brought on ice to the Parasitology Research Laboratory at Atatürk University. The fish were dissected. The obtained parasites were fixed with AFA, dyed with Mayer's Carmalum, and mounted with Canada Balsam.

Results: Forty-eight fish were infected with the Orientocreadium batrachoides. The prevalence of the parasite was $76.2 \%$ overall, and $100 \%$ in the largest size class of C. gariepinus. There was no significant correlation between fish size and number of parasites.

Conclusion: Our sample of C. gariepinus from the Asi River exhibited high rates of incidence of $O$. batrachoides which is the first record from Turkey. It was detected that the specimens of $O$. batrachoides in Turkey are larger than previously reported samples. This is the first clearly documented report of O. batrachoides in teleost fish of Turkey. (Turkiye Parazitol Derg 2013; 37: 203-7)
\end{abstract}

Key Words: Turkey, Asi River, Clarias gariepinus, Orientocreadium batrachoides

Received: 24.05.2013

Accepted: 20.06.2013

\section{ÖZET}

Amaç: Ülkemizde Clarias gariepinus'un parazit faunası üzerine çalışmalar yapılmış olmasına karşın digenea parazitleri ile ilgili pek fazla yayın bulunmamaktadır. Bu çalışmanın amacı Ülkemizin parazit faunasına bu yönde katkıda bulunmaktır.

Yöntemler: 2007-2008 yılları arasında Asi Nehrinden yakalanmış olan Clarias gariepinus'lar Hatay'daki balıkhanelerden satın alınarak buz içerisinde Atatürk Üniversitesi Parazitoloji Araştırma Laboratuvarı'na getirilmiştir. Balıkların diseksiyonu yapılmış, elde edilen parazitler AFA ile fikse edilmiş, Mayer's Carmalum ile boyanmış ve Kanada balzamı ile kalıı preparatları yapılmıştır.

Bulgular: Kırk sekiz balık Orientocreadium batrachoides ile enfekte olmuştur. Parazitlerin bütün balıklardaki prevalensi \%76,2, en büyük boy grubunda \%100'dür. Balık boyu ve parazit sayısı arasında önemli bir korelasyon bulunmadığı belirlenmiştir.

Sonuç: Türkiye'den ilk kez kaydedilen O. batrachoides Asi nehrinden yakalanan C. gariepinus'ta yüksek oranda rastlanmaktadır. Ülkemizden tespit edilen $O$. batrachoides'lerin boyutları daha önce tespit edilenlerden daha büyük olduğu belirlenmiştir. Bu çalışma Orientocreadium batrachoides'in Türkiye teeostlarındaki ilk kaydıdır. (Turkiye Parazitol Derg 2013; 37: 203-7)

Anahtar Sözcükler: Türkiye, Asi Nehri, Clarias gariepinus, Orientocreadium batrachoides Geliş Tarihi: 24.05.2013

Kabul Tarihi: 20.06.2013

This study was presented at the 20 th National Biology Congress, 21-25 June 2010, Denizli, Turkey. Bu çalışma 20. Ulusal Biyoloji Kongresi'nde sunulmuştur, 21-25 Haziran 2010, Denizli, Türkiye.

Address for Correspondence / Yazışma Adresi: Dr. Yahya Tepe, Department of Biology, Faculty of Medicine, Atatürk University, Erzurum, Turkey Phone: +90 4422314129 E-mail: tepeyahya@hotmail.com doi:10.5152/tpd.2013.45 


\section{INTRODUCTION}

Clarias gariepinus, the African catfish is widespread in the southern and central freshwaters of Turkey, including the Asi River (where it has commercial importance), the Ceyhan, Seyhan, Göksu, Aksu and Sakarya rivers. Clarias gariepinus is a benthopelagic, dioecious, omnivorous fish, and is widely tolerant of extreme environmental conditions (1). It is one of the most important fish species for aquaculture in Turkey. However, parasitic infections are known to cause massive mortality in the fry and fingerling stages, especially in high-density aquaculture systems (2).

Previous studies have illuminated many aspects of the biology of C. gariepinus that are useful for aquaculture (i.e., karyotype, (3); nuclear abnormalities, (4); hormone effects on growth, (5); natural growth rates, (1); reproductive biology, (6); and stomach contents, (7)). However, only two previous papers have reported on the parasite fauna of this species in Turkey $(8,9)$. Although both of these papers are important and useful, neither focuses on digenean parasites. Given the devastating effect of parasites, especially on younger age classes in aquaculture facilities, it is important to document and understand important parasites of this species in the wild. Our objective in this study is to document and describe a common digenean parasite of the African catfish of Turkey that has not previously been reported.

\section{METHODS}

From 2007 to 2008, a total 63 Clarias gariepinus that were caught in the Asi River were purchased from the fish market in Hatay (Turkey) and brought on ice to the Parasitology Research Laboratory at Atatürk University. We recorded the total length $(T L)$ of the fish in $\mathrm{cm}$, and then opened the abdominal cavity to search for digenean parasites. First, we macroscopically inspected the visceral organs and intestines, and then systematically inspected all material microscopically with an Olympus $\mathrm{BH}-2$ stereomicroscope. The obtained parasites were fixed with AFA, dyed with Mayer's Carmalum, and mounted according to standard methods (10). The identification of the parasite was established based on Tubangui (11) and Sirikantayakul (12).

\section{Statistical Analysis}

Parasitological quantitative descriptors were calculated according to Bush et al. (13) as follows: Prevalence (PREV), Mean Intensity (MI), Mean Abundance (MA). To test for a relationship between fish size and number of parasites found, we used a correlation analysis (IBM SPSS Statistics 20). Finally, we compared morphological measurements of parasites from our samples to those from the two previous studies on the same species to aid in identification in future samples $(11,12)$. Parasites and fish materials were preserved and stored in the Biology Department, Faculty of Science, at Atatürk University.

\section{RESULTS}

Of the total of 63 fish examined, 48 were infected with the digenean Orientocreadium batrachoides (Figure 1). The prevalence of the parasite in the sample was $76.2 \%$ overall, and $100 \%$ in the largest size class of C. gariepinus (Table 1). There was no significant correlation between fish size and number of parasites $\left(r^{2}=0.102, p=0.43\right)$ (Figure 2).

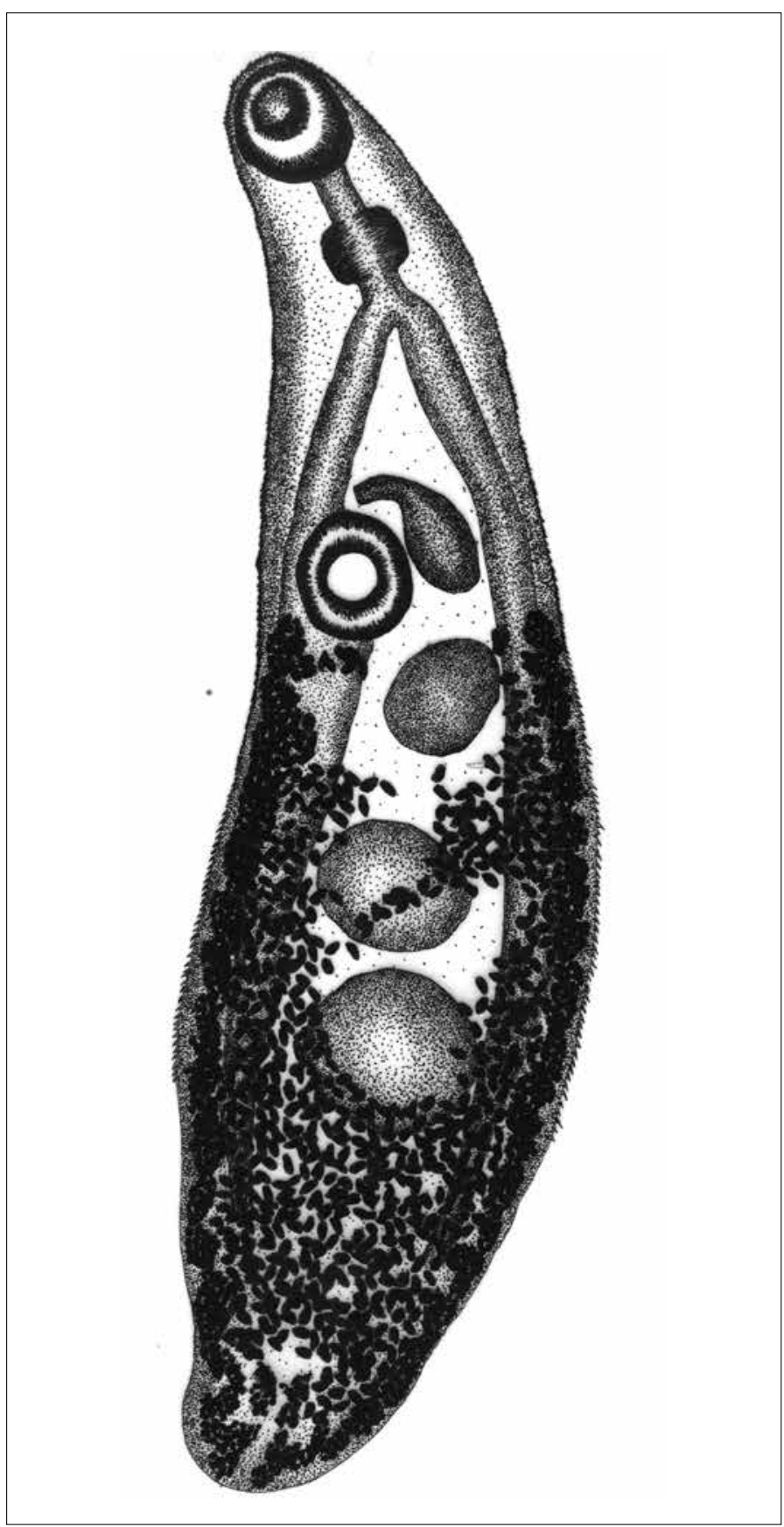

Figure 1. Orientocreadium batrachoides Tubangui, 1931 from Clarias gariepinus

Table 1. Distribution of $O$. batrachoides in size groups of $C$. gariepinus

\begin{tabular}{|l|c|c|c|c|c|c|c|}
\hline Size groups & EFN & IFN & TPN & MPS & PREV & MI & MA \\
\hline $21-30 \mathrm{~cm}$ & 16 & 13 & 190 & 43 & 0.813 & 11.875 & 14.615 \\
\hline $31-40 \mathrm{~cm}$ & 41 & 29 & 399 & 49 & 0.707 & 9.732 & 13.759 \\
\hline $41-50 \mathrm{~cm}$ & 6 & 6 & 121 & 89 & 1.000 & 20.167 & 20.167 \\
\hline Total & 63 & 48 & 710 & 89 & 0.762 & 11.270 & 14.792 \\
\hline
\end{tabular}

(EFN: Examined Fish Number; IFN: Infected Fish Number; TPN: Total Parasite Number; MPS: Maximum Parasite Number; PREV: Prevalence; MI: Mean Intensity; MA: Mean Abundance) 
Table 2. Morphometric measures of Orientocreadium batrachoides Tubangui, 1931

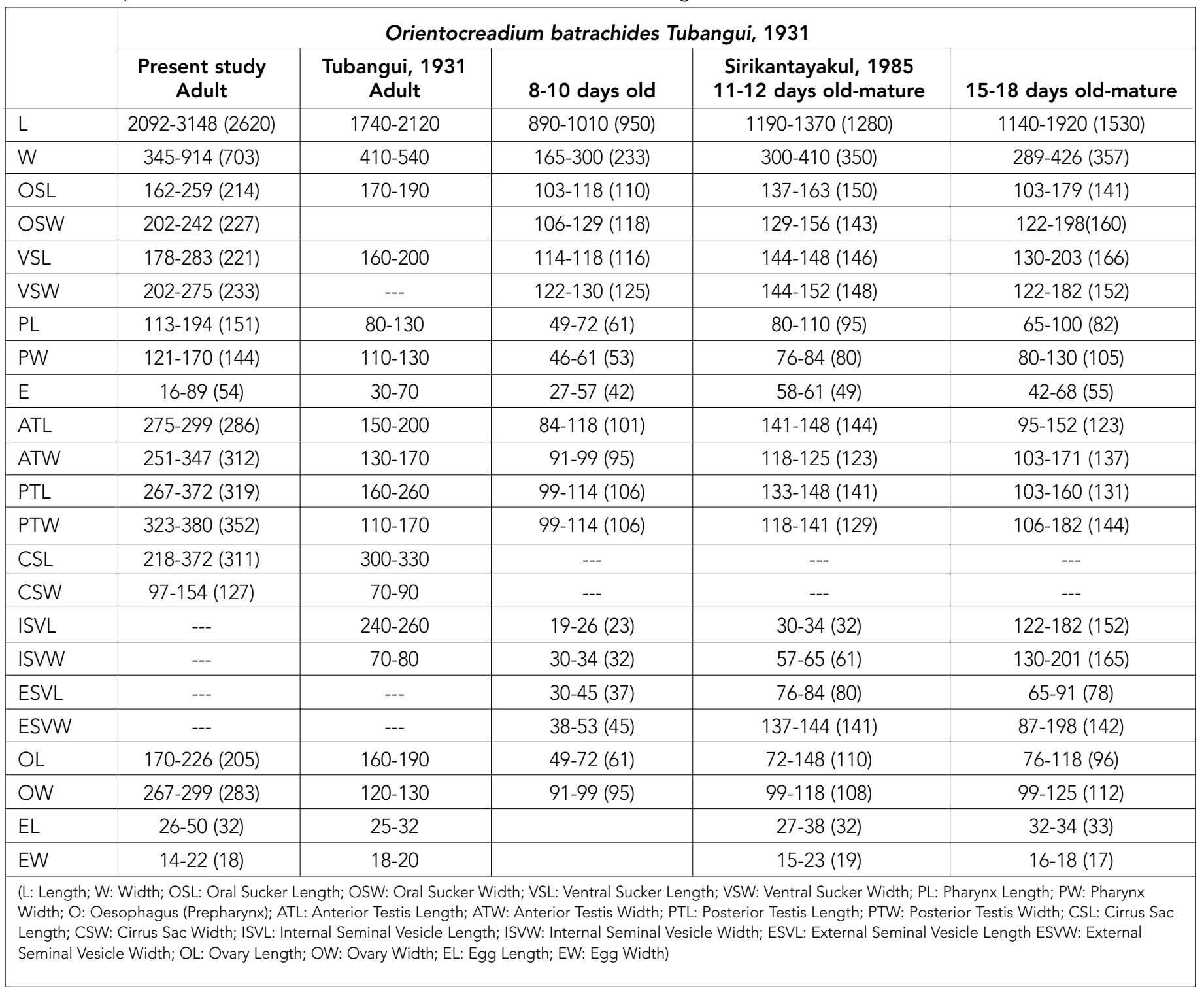

\section{Orientocreadiidae Yamaguti, 1958}

\section{Orientocreadium batrachoides Tubangui, 1931}

The body is ellipsoid and the anterior region is spinous. The oral sucker is slightly oval and the ventral sucker is larger than the anterior one. The pharynx is located behind the very short prepharynx. The caecum is bifurcated shortly after the pharynx. Testicles are tandem, slightly oval, postovarian and median. The anterior testis is smaller than the posterior. The cirrus sac is large and located to one side of the acetabulum. The ovary is oval, median, and located at the equator of the body. The uterus extends to the posterior end of the body. The eggs are numerous, small, and operculated. The vitelline follicles extend from the uterine level to the posterior end of the body. In general, specimens of $O$. batrachoides from $C$. gariepinus in Turkey are larger than previously reported samples (Figure 1, Table 2).

\section{DISCUSSION}

Orientocreadium batrachoides is a broadly distributed, hostspecific parasite first described from Clarias batrachus in the Philippines $(11,14)$. It has since been documented in Clarias macrocephala in the Philippines (12), in Clarias lazera in Egypt $(15,16)$, in Channa gachua in India (17), and in Clarias fuscus and Parasilurus asotus in China (14). In addition, Soylu and Emre (8) described a digenean parasite as Orientocreadium sp. from Clarias lazera in Turkey. Given the measurements and characteristics reported in this study, we suggest that this was Orientocreadium batrachoides.

Our sample of C. gariepinus from the Asi River exhibited high rates of incidence of $O$. batrachoides (76.2\%). Given this high rate of infection, it is surprising that this parasite has not been described previously in the fish of Turkey. It may be that this represents a relatively new invasion by the parasite in the Asi 


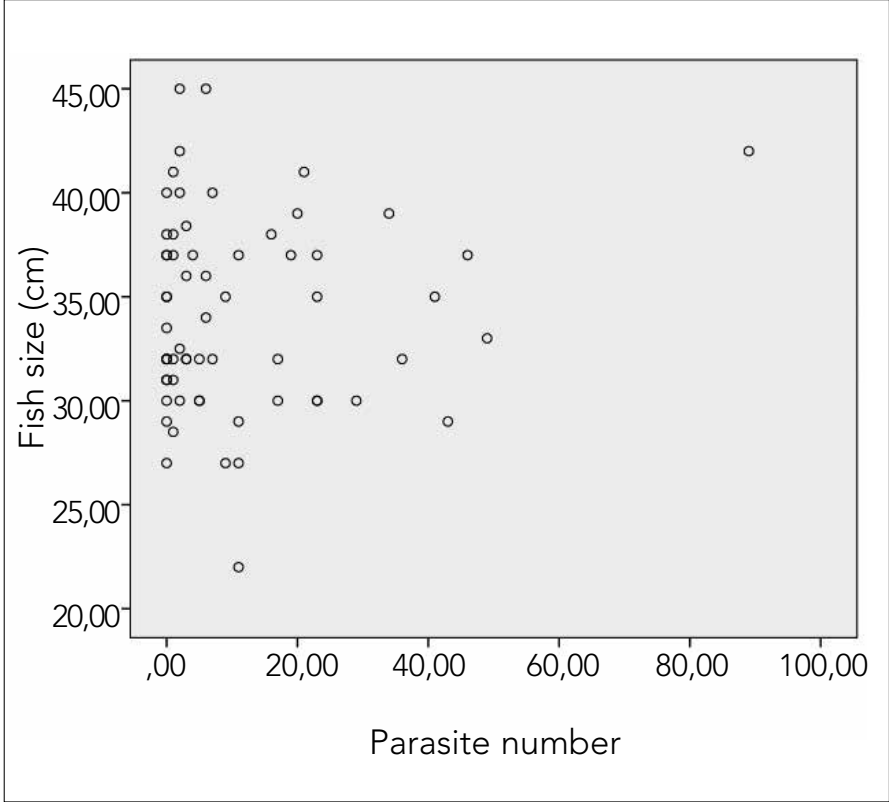

Figure 2. The scatterplot of the parasite numbers

River, possibly via the introduction of infected fishes from some other location. Alternatively, the parasite may be widespread, and the lack of prior documentation may simply reflect the lack of focused study. Intermediate hosts for $\mathrm{O}$. batrachoides include Lymnaea viridis (Mollusca) as the first intermediate host, and secondary intermediate hosts are mosquito larvae, aquatic worms, tadpoles, dragonfly nymphs and young fish (12). These intermediate hosts are widespread in the rivers of Turkey, and are common in the diet of C. gariepinus (7). Thus, we suggest that the distribution of $O$. batrachoides is likely to include much of the range of $C$. gariepinus in the freshwaters of Turkey.

\section{CONCLUSION}

C. gariepinus from the Asi River exhibited high rates of incidence of $O$. batrachoides which is the first record from Turkey. It was detected that the specimens of $O$. batrachoides in Turkey are larger than previously reported samples. This is the first clearly documented report of $O$. batrachoides in the teleost fish of Turkey.

\section{Conflict of Interest}

No conflict of interest was declared by the authors.

Peer-review: Externally peer-reviewed.

Informed Consent: Written informed consent was obtained from patients who participated in this study.

\section{Author Contributions}

Concept - Y.T.; Design - Y.T., M.C.O., M.B.; Supervision - M.C.O., M.B.; Funding - Y.T.; Materials - Y.T., R.Ö.; Data Collection and/ or Processing - Y.T., R.Ö.; Analysis and/or Interpretation - Y.T., M.C.O., M.B., R.Ö.; Literature Review - Y.T.; Writer - Y.T., M.C.O., M.B.; Critical Review - M.C.O., M.B.; Other - R.Ö.

\section{Acknowledgements}

We give special thanks to Dr. R.A. Bray (Department of Zoology, the Natural History Museum London, UK) for description of the parasite.

\section{Çıkar Çatışması}

Yazarlar herhangi bir çıkar çatışması bildirmemişlerdir.

Hakem değerlendirmesi: Dış bağımsız.

Hasta Onamı: Yazılı hasta onamı bu çalışmaya katılan hastalardan alınmıştır.

\section{Yazar Katkıları}

Fikir - Y.T.; Tasarım - Y.T., M.C.O., M.B.; Denetleme - M.C.O., M.B.; Kaynaklar - Y.T.; Malzemeler - Y.T., R.Ö.; Veri toplanması ve/veya işlemesi - Y.T., R.Ö.; Analiz ve/veya yorum - Y.T., M.C.O., M.B., R.Ö.; Literatür taraması - Y.T.; Yazıyı yazan - Y.T., M.C.O., M.B.; Eleştirel Inceleme - M.C.O., M.B.; Diğer - R.Ö.

\section{Teşekkür}

Dr. R.A. Bray'a (Londra Ulusal Tarih Müzesi, Zooloji Bölümü, Ingiltere) parazitlerin deskripsiyonunda yardımcı olduğu için teşekkür ederiz.

\section{REFERENCES}

1. Yalçın Ş, Solak K, Akyurt I. Growth of the catfish Clarias gariepinus (Clariidae) In The River Asi (Orontes) Turkey. Cybium 2002; 26: 163-72.

2. Abo Esa JFK. Study on some ectoparasitic diseases of catfish, Clarias gariepinus with their control by ginger Zingiber Officiale Mediterranean Aquaculture Journal 2008; 1: 1-9.

3. Ergene S, Portakal E, Karahan A. Karyological Analysis and Body Proportion of Catfish (Clariidae, Clarias lazera, Valenciennes, 1840) in the Göksu Delta Turkey. Tr J of Zoology 1999; 23: 423-6.

4. Ergene S, Çavaş T, Çelik A, Köleli N, Kaya F, Karahan A. Monitoring of nuclear abnormalities in peripheral erythrocytes of three fish species from the Göksu Delta (Turkey) genotoxic damage in relation to water pollution. Ecotoxicology 2007; 16: 385-91. [CrossRef]

5. Yılmaz E, Çek Ş, Mazlum Y. The Effects of Combined Phytoestrogen Administration on Growth Performance, Sex Differentiation and Body Composition of Sharp Tooth Catfish Clarias gariepinus (Burchell, 1822). Turkish Journal of Fisheries and Aquatic Sciences 2009; 9: 33-7. [CrossRef]

6. Yalçın Ş, Solak K, Akyurt I. Certain Reproductive Characteristics Of The Catfish (Clarias gariepinus Burchell, 1822) Living In The River Asi, Turkey Turk J Zool 2001; 25: 453-60.

7. Yalçın Ş, Akyurt I, Solak K. Stomach Contents of the Catfish (Clarias gariepinus Burchell, 1822) In the River Asi (Turkey). Turk J Zool 2001; 25: 461-8.

8. Soylu E, Emre Y. Metazoan Parasites of Clarias lazera Valenciennes 1840 And Carassius carassius (Linnaeus, 1758) From Kepez I Hydro Electric Power Plant Loading Pond Antalya Turkey. Turkish Journal of Fisheries and Aquatic Sciences2005; 5: 113-7.

9. Kayış Ş, Özcelep T, Çapkin E, Altınok I. Protozoan and Metazoan Parasites of Cultured Fish In Turkey And Their Applied Treatments. The Israeli Journal of Aquaculture Bamidgeh 2009; 61: 93-102.

10. Pritchard $\mathrm{MH}$, Kruse GO. The Collection And Preservation Of Animal Parasites. Technical Bulletin No 1. The Harold W Manter Laboratory University Of Nebraska Press 1982; 141.

11. Tubangui MA. Trematode Parasites of Philippine Vertebrates III. Flukes from Fish and Reptiles. Philippine Journal of Science 1931; 44: 417-22.

12. Sirikantayakul S. Observations on the Life Cycle and Egg-Shell of Orientocreadium batrachoides Tubangui 1931 (Trematoda: Allocreadiidae) In Clarias macrocephala Gunther 1864. The Philippine Journal of Science 1985; 114: 183-206.

13. Bush AO, Lafferty KD, Lotz JL, Shostak AW. Parasitology Meets Ecology On Its Own Terms Margolis et al. Revisited Journal of Parasitology Washington DC 1997; 83: 575-83. [CrossRef] 
14. Tang CC, Lin SM. On the Life-History of Orientocreadium batrachoides Tubangui, With a Consideration on the Phylogeny of the Superfamily Plagiorchioidea. Acta Zoologica Sinica 1973; 19: 11-25.

15. Fischthal JH, Kuntz RE. Trematode Parasites of Fishes from Egypt. Part VII Orientocreadium batrachoides Tubangui 1931 (Plagiorchioidea) from Clarias lazera with a Review of the Genus and Related Forms. The Journal of Parasitology 1963; 49: 451-64.
16. El-Mansy A, Hamada S, Hasan S, El-Sarnagawy D. Histopathology of farmed freshwater fish infested with different helminthes. Egypt $J$ Aquat Biol and Fish 2011; 15: 1- 13.

17. Bhure DB, Nanware SS. Studies On Piscian Trematode Orientocreadium batrachoides From Channa Gachua Recent Research in Science and Technology 2011; 3: 13-14. 